\title{
Article \\ Crop Establishment Methods and Integrated Nutrient Management Improve: Part I. Crop Performance, Water Productivity and Profitability of Rice (Oryza sativa L.) in the Lower Indo-Gangetic Plain, India
}

\author{
Ashim Midya ${ }^{1} \mathbb{D}$, Binoy Kumar Saren ${ }^{2}$, Joy Kumar Dey ${ }^{2} \mathbb{D}$, Sagar Maitra $^{3} \mathbb{D}$, Subhashisa Praharaj $^{3}$, \\ Dinkar Jagannath Gaikwad ${ }^{4}$, Ahmed Gaber ${ }^{5, *(D)}$, Walaa F. Alsanie ${ }^{6}$ and Akbar Hossain 7 ,*(D)
}

check for updates

Citation: Midya, A.; Saren, B.K.; Dey, J.K.; Maitra, S.; Praharaj, S.; Gaikwad, D.J.; Gaber, A.; Alsanie, W.F.; Hossain, A. Crop Establishment Methods and Integrated Nutrient Management Improve: Part I. Crop Performance, Water Productivity and Profitability of Rice (Oryza sativa L.) in the Lower Indo-Gangetic Plain, India. Agronomy 2021, 11, 1860. https://doi.org/ 10.3390/agronomy11091860

Academic Editor: Kestutis Romaneckas

Received: 30 August 2021 Accepted: 14 September 2021 Published: 16 September 2021

Publisher's Note: MDPI stays neutral with regard to jurisdictional claims in published maps and institutional affiliations.

Copyright: (c) 2021 by the authors. Licensee MDPI, Basel, Switzerland. This article is an open access article distributed under the terms and conditions of the Creative Commons Attribution (CC BY) license (https:/ / creativecommons.org/licenses/by/ $4.0 /)$.
1 Department of Agriculture, Government of West Bengal, Kolkata 700001, India; ashimbckv@gmail.com

2 Department of Agronomy, Institute of Agriculture, Visva-Bharati University, Sriniketan 731236, India; binoykumar.saren@visva-bharati.ac.in (B.K.S.); joykumardey7@gmail.com (J.K.D.)

3 Department of Agronomy and Agroforestry, Centurion University of Technology and Management, Rajaseetapuram 761211, India; sagar.maitra@cutm.ac.in (S.M.); subhashisa.praharaj@cutm.ac.in (S.P.)

4 Department of Biochemistry and Plant Physiology, Centurion University of Technology and Management, Rajaseetapuram 761211, India; gaikwad@cutm.ac.in

5 Department of Biology, College of Science, Taif University, Taif 21944, Saudi Arabia

6 Department of Clinical Laboratories Sciences, The Faculty of Applied Medical Sciences, Taif University, Taif 21944, Saudi Arabia; w.alsanie@tu.edu.sa

7 Bangladesh Wheat and Maize Research Institute, Dinajpur 5200, Bangladesh

* Correspondence: a.gaber@tu.edu.sa (A.G.); akbarhossainwrc@gmail.com (A.H.)

Abstract: In the eastern part of India, rice as the most vital staple food crop supports as well the livelihood security of a vast population. Rice is mostly grown under conventional flooded culture without proper nutrient management. Crop performance, water productivity and economic profitability of rice cultivation need to be assessed under water-saving rice production methodologies with proper integrated plant nutrient management strategies using locally available low-cost nutrient sources. A field trial was conducted at the Adaptive Research Farm, Polba (58.57 m msl), Agriculture Department, West Bengal, India, during the rainy/wet seasons of 2014 and 2015 under aerobic culture, the system of rice intensification (SRI) and conventional flooded culture. The experiment was conducted to evaluate the influence of integrated plant nutrition and water-saving rice production methodologies on the crop performance and water productivity of rice and analyse the economic profitability of rice under different nutritional management and crop production methods such as aerobic culture, conventional flooded and SRI with an objective of sustainability in rice cultivation in the agroclimatic region. The results revealed that crop productivity significantly $(p \leq 0.05)$ varied from $4.68 \mathrm{t} \mathrm{ha}^{-1}$ (average yield recorded under aerobic culture) to $6.21 \mathrm{t} \mathrm{ha}^{-1}$ (average yield as achieved under SRI). Cultivation of rice under aerobic and conventional culture resulted in $24.6 \%$ and $20.9 \%$ yield reduction respectively as compared to SRI. Integrating $75 \%$ of the recommended dose of nitrogen (RDN) through chemicals with $25 \%$ RDN from vermicompost resulted in maximum crop productivity irrespective of crop culture. Aerobic rice culture registered maximum water economy in terms of both irrigation water productivity and total productivity. The study concludes that, for maximization of economic profitability, value cost ratio and partial factor productivity of nutrients the SRI method can be adopted along with integrated nutrient management (75\% of RDN through chemicals with $25 \%$ RDN from vermicompost) in the lower Indo-Gangetic Plain Zone (IGPZ) of West Bengal, India.

Keywords: aerobic rice; economic profitability; root biomass; system of rice intensification; yield; water productivity 


\section{Introduction}

Rice is the vital staple food crop of the world [1,2], supports the livelihood of more than 100 million farm families [3] providing the energy requirement of billion of people and playing a pivotal role in the agro-ecosystem and biodiversity. Global requirements of rice are expected to be about 280 million tonnes produced in the next 30 years and feeding more than 9 billion people by 2050 will require doubling of production on a sustainable basis $[4,5]$. More than three-fourths of rice output in India is realized on 79 million ha of irrigated lowland and it is predicted that 17 out of 75 million hectares of Asia's flood irrigated rice crop will experience physical water scarcity and 22-million-hectare areas may experience economic water scarcity [6-8]. This clearly indicates a question about rice production sustainability in traditional wetland eco-system under flooded conditions. Moreover, arsenic pollution, nitrate contamination, chromium toxicity and methane emission in traditional rice culture threatens the issues pertaining to rice yield sustainability and profitability under the backdrop of a shrinking water resource base [8].

Various alternative water-wise crop establishment methodologies have been advocated [9] to address the issue of rice production to utilize every drop of water to produce more crops. Aerobic rice is a relatively new cropping methodology requiring less water and crop grown like upland crop under non-puddled, non-flooded and non-saturated soil conditions [10,11] with 50\% reduced rate of methane emission [12] and improvement in water productivity from 0.4 to $0.6 \mathrm{~kg} \mathrm{~m}^{-3}$ [13]. System of rice intensification (SRI), an environmentally benign water-saving production methodology, is gaining popularity and interest because of its potential to enhance the productivity of land, capital, water and labour used in rice with higher nutrient uptake of crops with enhanced partial factor productivity of nutrients [14-16].

Furthermore, it uses less quantities of seed and chemical inputs and promotes biotic activities in the root zone due to ample application of organic matter leading to increased productivity with substantial savings of external inputs, especially water $[17,18]$. The work focuses on the importance of water saving in rice cultivation by following alternate establishment methods keeping in mind the cost-effectiveness and yielding ability of such practices. Thus, the study considers the three important aspects of sustainability i.e., ecology, economy and food security altogether. The rice-wheat cropping system followed in IGP (Indo-Gangetic Plain) is water- and nutrient-intensive. Rice being a highwater demanding crop uses a huge amount of water. This has led to ground water depletion. Under such a scenario finding an economically viable crop establishment method that can sustainably increase yield without depleting the resource base heavily can be of great help. Earlier, Alam et al. [19] suggested that the performance of crop establishment methods are highly location-, situation- and crop management-specific and hence, there is ample scope for evaluation of methods for finding the appropriate one. Furthermore, Mahanta et al. [20] noted that transplanted rice yielded more than direct-seeded rice because of superior stand establishment with the former. In the present context of water shrinkage, the scope for adoption of SRI can be investigated in contrast to traditional transplanted rice as SRI enhances water productivity.

Imbalanced fertilizer application and low organic matter content of soil affects nutrient uptake and reduce crop production [21,22] in rice. Nutrient management options in water-saving crop production methodologies are of utmost importance as nutrient availability, mobility in soil and dynamics, and uptake by plants are greatly affected due to change in soil redox potential. Although conventional puddle transplanted rice has a beneficial effect on soil chemical fertility favouring better availability of nutrients, organic matter accumulation and biological nitrogen fixation to supplement the crop additional nitrogen [23], aerobic rice soil cannot approach to neutrality for positive redox potential deterring the availability of Fe and Mn. Rice in aerobic soil suffers from inadequacy in mineral nutrition as nutrient transport to soil via mass flow and diffusion slow down due to reduction in the soil moisture regime and higher heat capacity of soil moisture [24,25]. The benefit of green manuring is a lucrative and attractive nutrient management option for 
the rice growers of tropical countries [26] requiring a huge quantity of fresh water. Apart from the green manuring, compost, biofertilizer in nutrient management options, recent advances in research of brown manuring has assumed the utmost importance in water savings rice production methodologies and conservation agriculture in the Indo-Gangetic plain of India [27-29]. Development of suitable high-yielding rice genotypes and increasing adoption in the rainfed ecosystems [18] replacing the traditional ones in any cropping system may augment system productivity in the Indo-Gangetic plain zone of West Bengal, India. The present study has also attempted in understanding the effect of different INM (Integrated Nutrients Management) options and in this regard, different low cost and locally available inputs could play a significant role. Moreover, nutrient availability being a function of water availability in the soils may change in different establishment methods. A combination of organic and inorganic nutrient supply must be studied to ensure soil health. However, less information is available regarding the nutrient dynamics of such combinations under different establishment methods.

There is limited information on growth and yield parameters, crops and water productivity of rice grown under aerobic culture, conventional flooded condition and SRI along with INM options. Furthermore, economic profitability in terms of benefit:cost ratio, partial factor productivity of nutrients (PFP), and value cost ratio (VCR) under different nutrient management options in this zone have not been studied extensively. Such information is vital for identifying appropriate water-wise production methodology and suitable nutrient management options aiming futuristic advance agronomic research for maximizing crop as well as water productivity with economic profitability.

\section{Materials and Methods}

\subsection{Site Description}

The field trial was carried out at Sub-Divisional Adaptive Research Farm, Polba, Hooghly, West Bengal, India $\left(22.92^{\circ} \mathrm{N}, 88.30^{\circ} \mathrm{E}\right.$ and $58.57 \mathrm{~m}$ altitude from mean sea level) during the wet season (July to November) of 2014 and 2015. The physicochemical characteristics of the experimental soil are presented in Table 1.

Table 1. Initial soil characteristics of the experimental soil (0-20 $\mathrm{cm}$ depth) of the Field.

\begin{tabular}{ccc}
\hline Parameters & Analytical Values & References \\
\hline Available Nitrogen & $281.5 \mathrm{~kg} \mathrm{ha}^{-1}$ & {$[30]$} \\
Available Phosphorus & $62.5 \mathrm{~kg} \mathrm{ha}^{-1}$ & {$[31]$} \\
Available Potassium & $253.1 \mathrm{~kg} \mathrm{ha}^{-1}$ & {$[32]$} \\
Organic Carbon & $0.5 \%$ & {$[33]$} \\
pH & 7.01 & {$[34]$} \\
Available Zinc & $1.17 \mathrm{ppm}$ & {$[35]$} \\
Available Iron & $12.59 \mathrm{ppm}$ & {$[35]$} \\
Sulphur & $10.93 \mathrm{ppm}$ & {$[36]$} \\
Electrical Conductivity & $0.31 \mathrm{ds} \mathrm{m}^{-1}$ & {$[31]$} \\
Boron & $1.44 \mathrm{ppm}^{2}$ & {$[35]$} \\
Manganese & $3.16 \mathrm{ppm}$ & {$[35]$} \\
Copper & $0.24 \mathrm{ppm}$ & {$[35]$} \\
Soil Texture & Sandy loam & {$[37]$} \\
\hline
\end{tabular}

The experimental site is situated in a humid subtropical climate. The two years mean minimum and maximum temperatures ranged from $16.2{ }^{\circ} \mathrm{C}$ to $19.3{ }^{\circ} \mathrm{C}$ and $29.3^{\circ} \mathrm{C}$ to $30.2{ }^{\circ} \mathrm{C}$, respectively, with a total rainfall of $109.92 \mathrm{~mm}$ and $155.53 \mathrm{~mm}$ received during the cropping season of 2014 and 2015, respectively (Figures 1 and 2). 


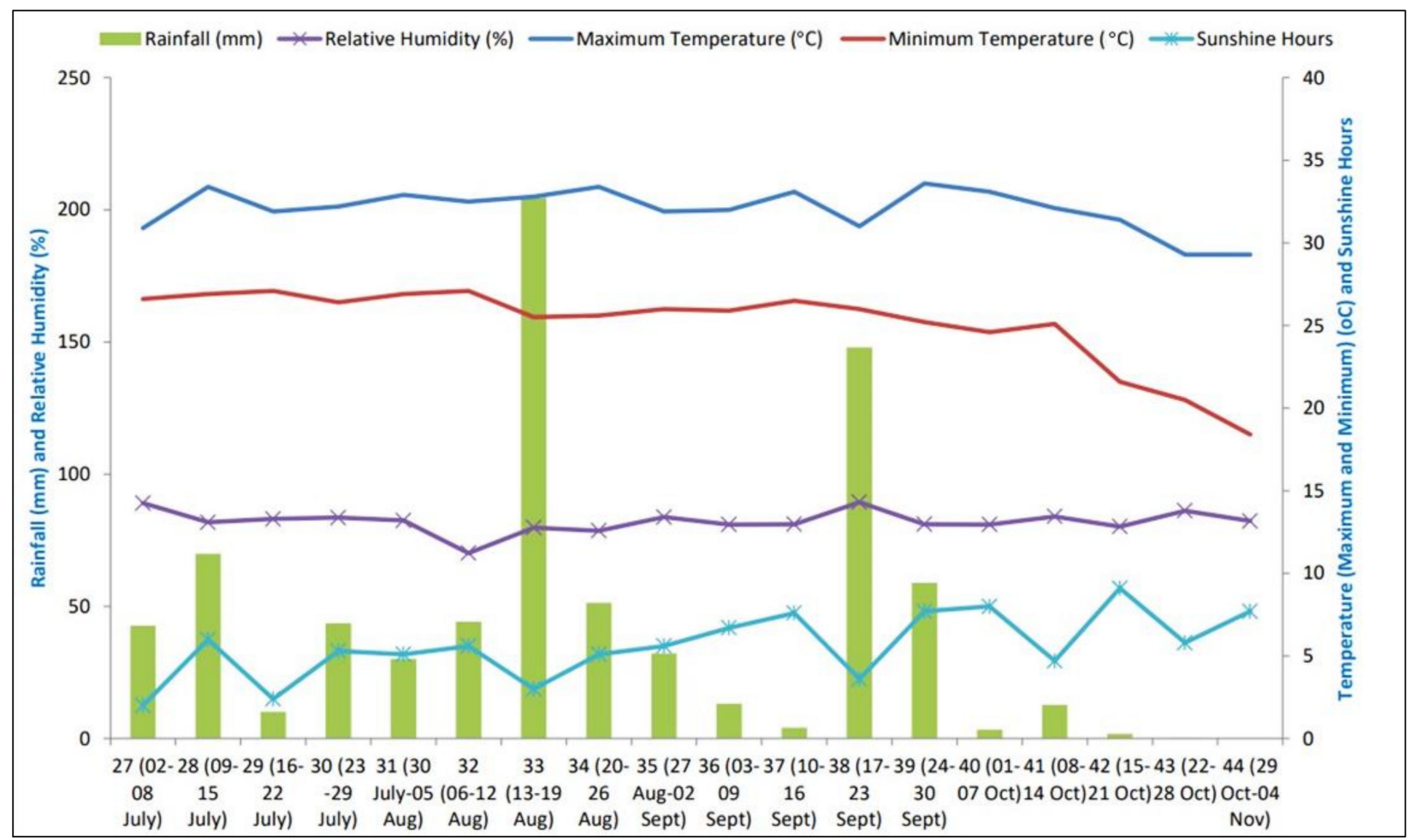

Figure 1. Weather parameters during the experimental period during 2014.

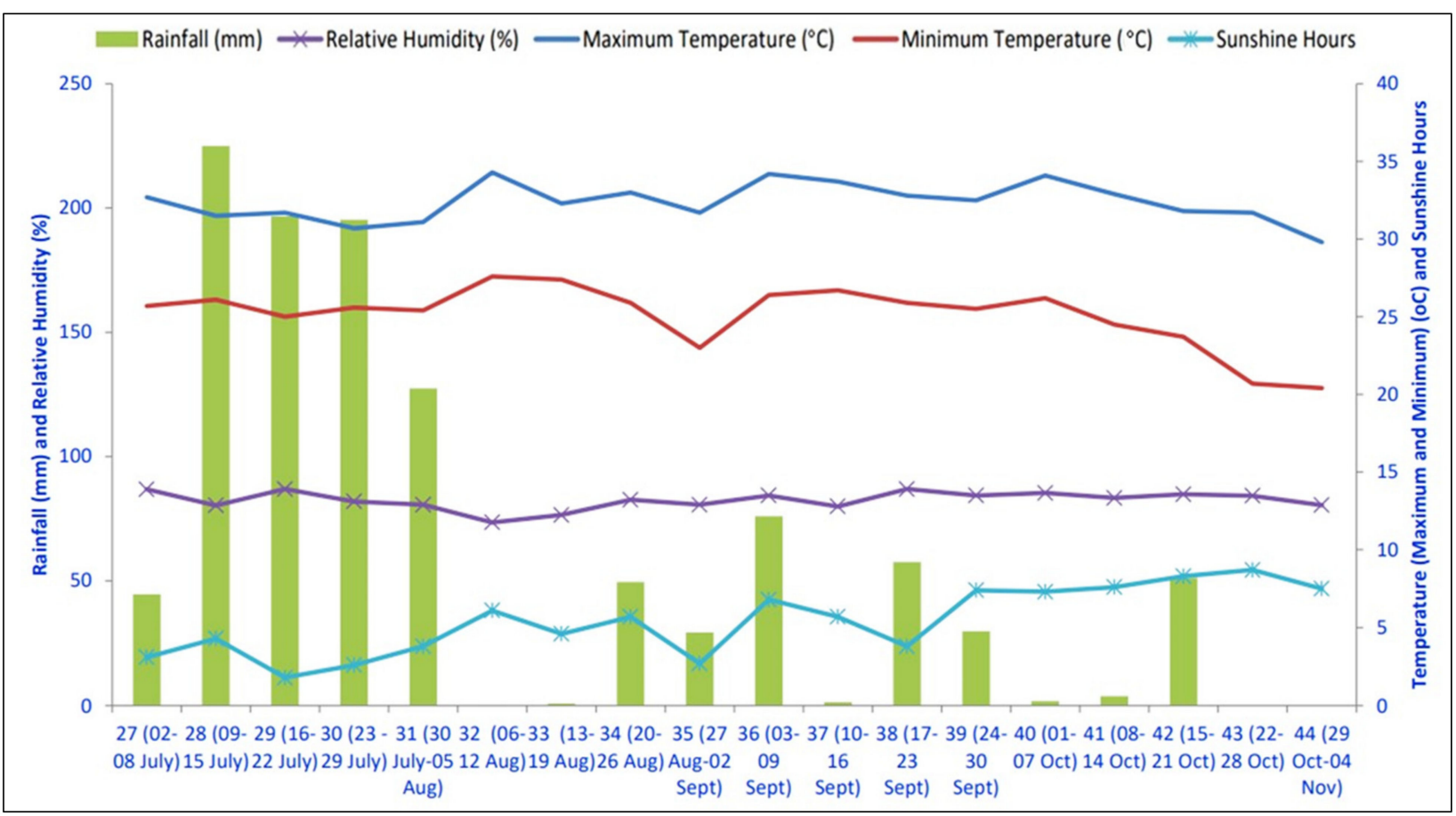

Figure 2. Weather parameter during the experimental period during 2015.

\subsection{Treatments and Field Layout}

The experimental treatments comprised of three crop establishment methodologies, $\mathrm{T}_{1}$ : aerobic culture., $\mathrm{T}_{2}$ : SRI., $\mathrm{T}_{3}$ : conventional flooded transplanted rice (CTR) culture were taken in main plots and eight nutrient management treatments, namely, $\mathrm{F}_{1}$ : absolute control, $\mathrm{F}_{2}: 100 \%$ recommended dose of fertilizers (RDF) through the chemical form $\left(80 \mathrm{~kg} \mathrm{~N} \mathrm{ha}^{-1}\right.$, $\left.40 \mathrm{~kg} \mathrm{P}_{2} \mathrm{O}_{5} \mathrm{ha}^{-1}, 40 \mathrm{~kg} \mathrm{~K}_{2} \mathrm{O} \mathrm{ha}^{-1}\right), \mathrm{F}_{3}: 75 \%$ recommended dose of nitrogen (RDN) through chemical fertilizer $+25 \%$ RDN through farmyard manure (FYM), $\mathrm{F}_{4}: 75 \%$ RDN through 
chemical fertilizer $+25 \%$ RDN through vermicompost, $\mathrm{F}_{5}: 50 \% \mathrm{RDN}$ through chemical fertilizer $+25 \%$ RDN through FYM (farmyard manure) + brown manuring (co-culture of Dhaincha (Sesbania aculeate Poir.) at $30 \mathrm{~kg} \mathrm{ha}^{-1}$ and knocking down with the application of 2-4 D ethyl ester at $0.75 \mathrm{~kg}$ a.i. ha ${ }^{-1}$ ), $\mathrm{F}_{6}: 50 \%$ RDN through chemical fertilizer $+25 \%$ RDN through vermicompost + brown manuring, $\mathrm{F}_{7}: \mathrm{F}_{5}+$ soil application of biofertilizer bacteria (Azospirillium brassilense) at $2 \mathrm{~kg} \mathrm{ha}^{-1}, \mathrm{~F}_{8}: \mathrm{F}_{6}+$ soil application of biofertilizer Azospirillium brassilense at $2 \mathrm{~kg} \mathrm{ha}^{-1}$ were considered in sub-plots. These treatment combinations were laid out in a split-plot design and replicated thrice. Sub-plot size was $12 \mathrm{~m}^{2}$ each. The measured quantity of irrigation water at $3.0 \mathrm{~cm}, 4.0 \mathrm{~cm}$ and $5.0 \mathrm{~cm}$ depths of water in case of aerobic culture, SRI and CTR, respectively, was applied during both seasons of the experiment. The number of irrigations was eight in 2014, whereas the frequency of irrigation was six in 2015 depending on the intensity and quantity of rainfall during the study period. Sufficient drainage channels were created in aerobic plots to reduce the impact of rain along with a suitable buffer drainage channel to restrict water seepage from the flooded to aerobic plots.

\subsection{Crop Culture}

The pre-germinated seeds of the rice variety 'CR Dhan 304 ' were directly seeded at a spacing of $20 \mathrm{~cm} \times 15 \mathrm{~cm}$ in aerobic culture, whereas seedlings aged 12 days raised in the nursery were transplanted singly at a spacing of $25 \mathrm{~cm} \times 25 \mathrm{~cm}$ in case of SRI and seedlings aged 24 days were transplanted with three seedlings per hill at a spacing of $20 \mathrm{~cm} \times 15 \mathrm{~cm}$ in the case of conventional flooded rice culture. The entire dose of phosphorus (40 kg $\mathrm{P}_{2} \mathrm{O}_{5} \mathrm{ha}^{-1}$ as single super phosphate) and potassium ( $40 \mathrm{~kg} \mathrm{~K} \mathrm{~K}_{2} \mathrm{O}$ as muriate of potash) were applied as basal to all the treatments at the time of final land preparation. Nitrogen fertilizer at $80 \mathrm{~kg} \mathrm{ha}^{-1}$ as urea was applied in three proportions, such as one-fourth as basal, half at maximum tillering stage and remaining one-fourth at the panicle initiation stage, in the case of the treatment where plant nutrition was supplied solely from chemical fertilizer. Under integrated nutrient management treatments a proportionate amount of nitrogenous fertilizer was applied and a substituted amount of organic sources of nutrients was applied 20 days before the application of chemical fertilizer. Specific bio-fertilizer was applied along with organic sources of nutrients as per treatment. Brown manuring was practiced as per the standard procedure. Two hand weedings were done at 25 and 40 days after transplanting (DAT). The rest of the recommended package of practices for integrated crop management for achieving maximum productivity of the crop were followed.

\subsection{Plant Sampling}

Periodical observations were recorded at different growth stages of the crop to determine above-ground biomass, root biomass from $1 \mathrm{~m}^{2}$ plot area as per the standard procedure of destructive sampling. Twenty hills were sampled at the maturity stage in zigzag mode from a $5 \mathrm{~m}^{2}$ harvest area to estimate yield components and harvest index. After separation from panicles, the dry weight of straw was determined after oven drying at $70{ }^{\circ} \mathrm{C}$ temperature to constant weight. Panicles were threshed and filled and unfilled grains were separated. Above ground total biomass at harvest was determined by integrating total dry matter of straw, rachis and total spikelets. Spikelet per panicle, ripening ratio (ratio of filled spikelets to total spikelet multiplied by 100), and harvest index $(100 \times$ grain weight/total biomass) were calculated. Crop yield was determined after harvesting from the sampling area within each net plot and dried to a moisture content of $0.14 \mathrm{~g} \mathrm{H}_{2} \mathrm{O} \mathrm{g}^{-1}$ of fresh weight.

\subsection{Computation of Water Productivity, Partial Factor Productivity of Nutrients (PFP), Value Cost Ratio (VCR) and Economic Profitability}

The measured quantity of irrigation water through a water meter as described earlier was applied under different crop establishment methods. In the situation of heavy rainfall, excess rainwater was drained off to maintain the accumulated water within the maximum allowable depths. Drainage depth was also calculated from the field water depth before 
and after drainage. Water balance within a field during the crop season was expressed as: I (irrigation) + R (rainfall)-ET (evapotranspiration) - D (drainage depth) - SP (net seepage and percolation including capillary rise) $=$ Change in-field water storage. The total quantity of irrigation input was calculated by integrating the measured quantities of water applied throughout the cropping period and converted into the volume of water Irrigation water productivity was computed by dividing $\mathrm{kg}$ grain yield produced $\mathrm{m}^{-3}$ irrigation input applied. Likewise, total water productivity was calculated by dividing $\mathrm{kg}$ grain yield produced $\mathrm{m}^{-3}$ of total water input utilized inclusive of effective rainfall.

Partial factor productivity of nutrients was estimated by dividing rice grain yield with the amount of fertilizer nutrients. The value cost ratio was estimated by dividing the value of additional yield as the numerator and the value of fertilizer used as the denominator. Economic profitability was calculated simply from the cost of cultivation and gross return accrued from different crop cultures under various nutrient management treatments and subsequently net return, where the cost of cultivation was subtracted from gross return and benefit-cost ratio by dividing net return with cost component.

\subsection{Statistical Analysis}

All data related to crop and soil were statistically analyzed using a split-plot model. The treatment effects on different parameters were tested by two-way analysis of variance (ANOVA), and treatment means comparisons among the treatments were made using the least significant difference (LSD) tests at a $5 \%$ level of probability $(p \leq 0.05)$. Statistical procedures were carried out with the software program Statistix (Statistix Inc., Tallahassee, FL, USA) [38].

\section{Results}

\subsection{Growth Parameters of Rice Are Influenced by Crop Establishment Methods and Integrated Nutrient Management}

The height of the plant was significantly $(p \leq 0.05)$ higher with conventional flooded rice than aerobic culture, but statistically at par with SRI (Table 2). A significant reduction in plant height of all nutrient management treatments under aerobic situation noted in comparison to other crop production methodologies might be due to retarded cell elongation resulting in a reduced intermodal length that ultimately showed the shortest plant under aerobic crop culture. Although the interaction effect of crop establishment methodologies and integrated nutrient management practices was not significant in respect to plant height, significant $(p \leq 0.05)$ differences in terms of nutrient management practices were observed over absolute control.

The highest plant height of $134.58 \mathrm{~cm}$ was recorded under integrated nutrient management treatment where $50 \%$ RDN was applied through chemical fertilizer and $25 \%$ RDN was applied through vermicompost coupled with brown manuring and bio-fertilizer and this treatment was at par with the rest of the nutrient management practice. The highest number of tillers $\mathrm{m}^{-2}$ (654.1) was achieved under conventional flooded rice that significantly differed from both aerobic culture and SRI. Integration of 25\% RDN through vermicompost with 75\% RDN from chemical fertilizer produced the maximum number of tillers $\mathrm{m}^{-2}$ irrespective of crop production methodologies. At harvest, tillers (unit land area) under this treatment were significantly higher over absolute control and $\mathrm{F}_{5}$ and $\mathrm{F}_{6}$ treatments where $50 \%$ RDN was applied through chemical fertilizer and 25\% RDN was applied through farmyard manure or vermicompost coupled with brown manuring. Total dry matter (TDM) production was found to be significantly higher under the SRI as compared to aerobic culture. The TDM production was highest $\left(1235 \mathrm{~g} \mathrm{~m}^{-2}\right)$ under plant nutrition solely supplied through chemical sources and followed by an integrated nutrient management package where 50\% RDN through chemical sources integrated with $25 \%$ RDN through vermicompost, brown manuring and bio-fertilizer. The least TDM was produced under absolute control treatment. 
Table 2. Crop establishment methods and integrated nutrient management influenced the growth parameters of rice.

\begin{tabular}{|c|c|c|c|c|c|c|c|c|c|c|c|c|c|c|c|}
\hline \multirow{2}{*}{ Treatments } & \multicolumn{3}{|c|}{$\begin{array}{l}\text { Plant Height at Harvest } \\
(\mathrm{cm})\end{array}$} & \multicolumn{3}{|c|}{ Tillers $\mathrm{m}^{-2}$ at Harvest } & \multicolumn{3}{|c|}{$\begin{array}{l}\text { The Total Dry Matter at Harvest } \\
\qquad\left(\mathrm{g} \mathrm{m}^{-2}\right)\end{array}$} & \multicolumn{3}{|c|}{$\begin{array}{l}\text { Root Biomass at Harvest } \\
\qquad\left(\mathrm{g} \mathrm{m}^{-2}\right)\end{array}$} & \multicolumn{3}{|c|}{ Days to Maturity } \\
\hline & Y1 & Y2 & Mean & Y1 & $\mathrm{Y} 2$ & Mean & Y1 & Y2 & Mean & Y1 & $\mathrm{Y} 2$ & Mean & Y1 & $\mathrm{Y} 2$ & Mean \\
\hline \multicolumn{16}{|c|}{ Crop Establishment Methods } \\
\hline $\mathrm{T}_{1}$ & 121.31 & 117.87 & 119.59 & 461.9 & 469.2 & 465.5 & 902.3 & 920.5 & 911.4 & 430.4 & 444.8 & 437.6 & 120.8 & 122.6 & 121.7 \\
\hline $\mathrm{T}_{2}$ & 130.42 & 135.82 & 133.12 & 550.6 & 560.4 & 555.5 & 1205.2 & 1239.7 & 1222.4 & 604.3 & 625.9 & 615.1 & 125.2 & 124.8 & 125.0 \\
\hline $\mathrm{T}_{3}$ & 133.57 & 137.89 & 135.73 & 649.3 & 658.9 & 654.1 & 1196.4 & 1220.8 & 1208.6 & 577.2 & 548.8 & 563.0 & 129.3 & 130.0 & 129.6 \\
\hline $\mathrm{SE} \pm$ & 2.94 & 1.97 & 2.45 & 11.5 & 17.8 & 14.6 & 17.8 & 17.2 & 17.5 & 10.81 & 11.24 & 11.02 & 0.21 & 0.27 & 0.24 \\
\hline $\operatorname{LSD}_{0.05}$ & 9.10 & 7.84 & 8.47 & 45.2 & 70.1 & 57.6 & 69.7 & 67.5 & 68.6 & 42.46 & 44.15 & 43.30 & 0.87 & 1.06 & 0.96 \\
\hline CV $(\%)$ & 11.2 & 7.5 & 9.3 & 10.2 & 15.7 & 12.9 & 9.8 & 8.4 & 9.1 & 9.8 & 10.3 & 10.0 & 5.8 & 6.2 & 6.0 \\
\hline \multicolumn{16}{|c|}{ Integrated Nutrient Management } \\
\hline $\mathrm{F}_{1}$ & 106.44 & 108.13 & 107.28 & 245.9 & 240.3 & 243.1 & 600.7 & 626.0 & 613.3 & 214.8 & 203.7 & 209.2 & 123.9 & 124.2 & 124.0 \\
\hline $\mathrm{F}_{2}$ & 132.29 & 133.58 & 132.93 & 612.3 & 609.1 & 610.7 & 1245.5 & 1224.7 & 1235.1 & 565.7 & 540.4 & 553.0 & 125.2 & 123.8 & 124.5 \\
\hline $\mathrm{F}_{3}$ & 129.91 & 132.75 & 131.33 & 614.4 & 625.5 & 619.9 & 1200.3 & 1217.4 & 1208.8 & 593.9 & 550.5 & 572.2 & 125.0 & 124.0 & 124.5 \\
\hline $\mathrm{F}_{4}$ & 132.96 & 134.54 & 133.75 & 623.7 & 630.6 & 627.1 & 1222.8 & 1205.4 & 1214.1 & 607.5 & 554.5 & 581.0 & 126.0 & 124.8 & 125.4 \\
\hline $\mathrm{F}_{5}$ & 127.52 & 129.62 & 128.57 & 535.4 & 550.8 & 543.1 & 1148.6 & 1178.0 & 1163.3 & 563.8 & 546.3 & 555.0 & 126.8 & 125.0 & 125.9 \\
\hline $\mathrm{F}_{6}$ & 126.51 & 131.59 & 129.05 & 562.7 & 557.4 & 560.0 & 1164.4 & 1189.9 & 1177.1 & 574.2 & 558.8 & 566.5 & 124.9 & 123.0 & 123.9 \\
\hline $\mathrm{F}_{7}^{0}$ & 129.08 & 137.12 & 133.1 & 583.2 & 612.3 & 597.7 & 1180.8 & 1217.7 & 1199.2 & 577.8 & 552.3 & 565.0 & 126.2 & 125.6 & 125.9 \\
\hline $\mathrm{F}_{8}$ & 133.81 & 135.36 & 134.58 & 615.7 & 621.6 & 618.6 & 1204.1 & 1241.3 & 1222.7 & 591.3 & 574.3 & 582.8 & 124.8 & 126.0 & 125.4 \\
\hline $\mathrm{SE} \pm$ & 1.95 & 2.39 & 1.08 & 21.3 & 18.2 & 19.7 & 12.8 & 14.9 & 13.85 & 11.61 & 11.07 & 11.34 & 0.32 & 0.41 & 0.36 \\
\hline $\mathrm{LSD}_{0.05}$ & 5.56 & 6.83 & 6.19 & 60.8 & 51.9 & 56.3 & 35.3 & 42.8 & 39.05 & 33.14 & 31.59 & 32.36 & NS & NS & NS \\
\hline \multicolumn{16}{|c|}{ Interaction } \\
\hline \multicolumn{16}{|c|}{ Crop establishment methods $X$ Integrated nutrient management } \\
\hline $\mathrm{SE} \pm$ & 0.88 & 0.90 & 0.89 & 7.4 & 7.0 & 7.2 & 5.8 & 6.1 & 5.95 & 4.43 & 4.32 & 4.37 & 0.11 & 0.14 & 0.12 \\
\hline $\mathrm{LSD}_{0.05}$ & NS & NS & NS & 21.2 & 20.1 & 20.6 & 15.9 & 17.3 & 16.6 & 12.64 & 12.33 & 12.48 & NS & NS & NS \\
\hline \multicolumn{16}{|c|}{ Integrated nutrient management $X$ Crop establishment methods } \\
\hline $\mathrm{SE} \pm$ & 3.37 & 4.14 & 3.75 & 36.9 & 31.5 & 34.2 & 22.8 & 25.9 & 24.35 & 20.11 & 19.17 & 19.64 & 0.56 & 0.71 & 0.63 \\
\hline $\mathrm{LSD}_{0.05}$ & NS & NS & NS & 105.3 & 89.9 & 97.6 & 65.1 & 74.1 & 69.6 & 57.40 & 54.73 & 56.06 & NS & NS & NS \\
\hline
\end{tabular}

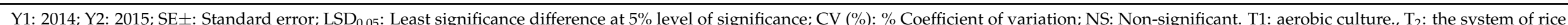

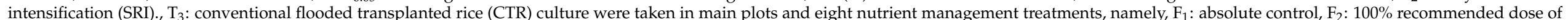

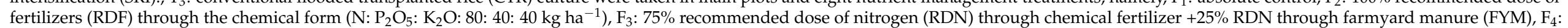

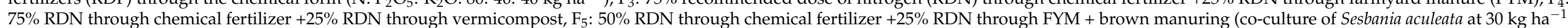

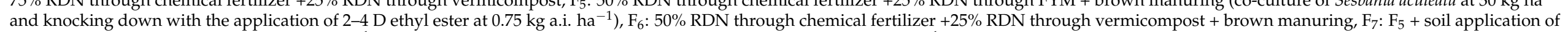
biofertilizer Azospirillium brassilense at $2 \mathrm{~kg} \mathrm{ha}^{-1}, \mathrm{~F}_{8}: \mathrm{F}_{6}$ + soil application of biofertilizer Azospirillium brassilense at $2 \mathrm{~kg} \mathrm{ha}^{-1}$ were considered in sub-plots. 
Irrespective of crop production methodologies, root biomass reached its peak at 90 DAS, i.e., during the stage of flowering and the highest root biomass was observed under flooded culture compared to aerobic culture and SRI. On the contrary, at harvest, root biomass was significantly higher under SRI in comparison to aerobic and flooded culture. Root biomass recorded under all integrated plant nutrition management treatments was higher over absolute control and the treatment where $100 \%$ recommended dose of fertilizer was applied, and the highest numerical value of $582.8 \mathrm{~g} \mathrm{~m}^{-2}$ root biomass was achieved under $\mathrm{F}_{8}$ that reflected the beneficial role of bio-fertilizer for promoting biotic activities within the rhizosphere. The interaction effect of crop production methods and integrated nutrient management was found to be significant $(p \leq 0.05)$ in respect to tillers number, total dry matter production and total root biomass per unit area. Although integrated nutrient management treatments have not any significant effect on days to $50 \%$ flowering and days to maturity, crops raised under aerobic culture matured significantly earlier as compared to the rest of the crop production methodologies. A significant delay in crop maturity was observed under flooded rice culture than aerobic rice and SRI.

\subsection{Yield Attributes of Rice Are Influenced by Crop Establishment Methods and Integrated Nutrient Management}

Data on yield attributing characters showed that SRI and flood-irrigated rice culture had significantly $(p \leq 0.05)$ superior values of yield attributes such as productive tillers $\mathrm{m}^{-2}$, total spikelets panicle ${ }^{-1}$, effective spikelets panicle ${ }^{-1}$, ripening ratio and 1000-grain weight compared to aerobic treatments. Although the total number of tillers (unit area) ${ }^{-1}$ was highest under conventional flood irrigated rice, effective tillers $\mathrm{m}^{-2}$ was highest under SRI (Table 3).

The highest number of productive tillers (unit area) $)^{-1}\left(558.2 \mathrm{~m}^{-2}\right)$ was recorded under integrated nutrient management treatment that substituted $25 \%$ RDN through farmyard manure $\left(\mathrm{F}_{3}\right)$, whereas the total number of spikelets panicle ${ }^{-1}(275.4)$ and effective spikelets panicle $^{-1}$ (247.1) was highest under the treatment where $25 \%$ RDN was applied through vermicompost and $75 \%$ RDN supplied through chemical fertilizers $\left(\mathrm{F}_{4}\right)$. The ripening ratio which represented the grain filling capacity of the crop was highest (90.5) under integrated plant nutrition supply through 50\% RDN by chemical, 25\% RDN through FYM or vermicompost, brown manuring and bio-fertilizer. The 1000-grain weight of rice followed a more or less similar trend. All nutrient management treatments significantly improved yield-attributing characters over absolute control under aerobic, flood-irrigated conditions and SRI. The interaction effect of crop establishment methods and integrated nutrient management (INM) was significant in relation to the yield attributes viz. productive tillers (unit area $^{-1}$, total spikelets panicle ${ }^{-1}$ and effective spikelets panicle ${ }^{-1}$ however, the interaction effect was found to be non-significant in case of ripening ratio and 1000-grain weight. 
Table 3. Crop establishment methods and integrated nutrient management influenced the yield attributes of rice.

\begin{tabular}{|c|c|c|c|c|c|c|c|c|c|c|c|c|c|c|c|}
\hline \multirow{2}{*}{ Treatments } & \multicolumn{3}{|c|}{$\begin{array}{l}\text { Productive Tillers } \\
\quad\left(\text { no. } \mathrm{m}^{-2}\right)\end{array}$} & \multicolumn{3}{|c|}{$\begin{array}{l}\text { Total Spikelets } \\
\text { Panicle }^{-1} \text { (no.) }\end{array}$} & \multicolumn{3}{|c|}{$\begin{array}{l}\text { Effective Spikelets } \\
\text { Panicle }^{-1} \text { (no.) }\end{array}$} & \multicolumn{3}{|c|}{$\begin{array}{c}\text { Ripening Ratio } \\
(\%)\end{array}$} & \multicolumn{3}{|c|}{$\begin{array}{l}\text { 1000-Grain Weight } \\
\text { (g) }\end{array}$} \\
\hline & $\mathrm{Y} 1$ & $\mathrm{Y} 2$ & Mean & Y1 & $\mathrm{Y} 2$ & Mean & $\mathrm{Y} 1$ & $\mathrm{Y} 2$ & Mean & $\mathrm{Y} 1$ & $\mathrm{Y} 2$ & Mean & Y1 & $\mathrm{Y} 2$ & Mean \\
\hline \multicolumn{16}{|c|}{ Crop Establishment Methods } \\
\hline $\mathrm{T}_{1}$ & 400.5 & 394.9 & 397.7 & 208.5 & 213.4 & 210.9 & 164.1 & 170.2 & 167.1 & 78.7 & 79.6 & 79.1 & 26.9 & 25.8 & 26.3 \\
\hline $\mathrm{T}_{2}$ & 519.4 & 535.4 & 527.4 & 262.4 & 264.0 & 263.2 & 243.7 & 239.4 & 241.5 & 92.8 & 90.6 & 91.7 & 27.1 & 27.7 & 27.4 \\
\hline $\mathrm{T}_{3}$ & 515.6 & 529.3 & 522.4 & 259.9 & 260.9 & 260.3 & 240.6 & 235.9 & 238.2 & 92.9 & 90.3 & 91.6 & 27.3 & 27.9 & 27.6 \\
\hline $\mathrm{SE} \pm$ & 5.60 & 6.10 & 5.8 & 2.88 & 2.28 & 2.58 & 1.87 & 1.20 & 1.53 & 0.72 & 1.09 & 0.90 & 0.07 & 0.09 & 0.08 \\
\hline CV $(\%)$ & 8.4 & 9.8 & 9.1 & 10.8 & 9.2 & 10.0 & 9.6 & 8.4 & 9.0 & 7.1 & 6.2 & 6.6 & 7.8 & 8.9 & 8.3 \\
\hline \multicolumn{16}{|c|}{ Integrated Nutrient Management } \\
\hline $\mathrm{F}_{1}$ & 313.3 & 306.0 & 309.6 & 130.0 & 128.2 & 129.1 & 93.5 & 91.6 & 92.5 & 71.9 & 71.4 & 71.6 & 26.3 & 25.7 & 26.0 \\
\hline $\mathrm{F}_{2}$ & 555.1 & 548.7 & 551.9 & 274.8 & 269.2 & 272.0 & 240.7 & 232.5 & 236.6 & 87.5 & 86.3 & 86.9 & 27.1 & 27.3 & 27.2 \\
\hline $\mathrm{F}_{3}$ & 550.9 & 565.6 & 558.2 & 261.2 & 268.5 & 264.8 & 239.2 & 238.0 & 238.6 & 91.5 & 88.6 & 90.0 & 27.4 & 26.3 & 26.8 \\
\hline $\mathrm{F}_{4}$ & 540.4 & 560.5 & 550.4 & 274.0 & 276.8 & 275.4 & 249.0 & 245.3 & 247.1 & 90.8 & 88.5 & 89.6 & 26.8 & 27.0 & 26.9 \\
\hline $\mathrm{F}_{5}$ & 482.7 & 475.8 & 479.2 & 247.7 & 245.6 & 246.6 & 223.4 & 217.5 & 220.4 & 90.1 & 88.4 & 89.2 & 27.3 & 27.6 & 27.4 \\
\hline $\mathrm{F}_{6}$ & 497.8 & 489.6 & 493.7 & 258.3 & 255.4 & 256.8 & 229.0 & 224.4 & 226.7 & 88.6 & 87.8 & 88.2 & 27.0 & 26.7 & 26.8 \\
\hline $\mathrm{SE} \pm$ & 3.80 & 2.76 & 3.28 & 3.26 & 1.89 & 2.57 & 3.31 & 3.66 & 3.48 & 1.48 & 1.54 & 1.51 & 0.16 & 0.13 & 0.14 \\
\hline $\mathrm{LSD}_{0.05}$ & 12.8 & 10.6 & 11.7 & 9.31 & 5.40 & 7.35 & 9.44 & 10.5 & 9.97 & 4.24 & 4.41 & 4.32 & 0.45 & 0.37 & 0.41 \\
\hline CV $(\%)$ & 6.2 & 7.9 & 7.0 & 8.6 & 7.4 & 8.0 & 6.9 & 5.2 & 6.0 & 5.1 & 5.4 & 5.2 & 5.7 & 7.5 & 6.6 \\
\hline \multicolumn{16}{|c|}{ Interaction } \\
\hline \multicolumn{16}{|c|}{ Crop establishment methods $\times$ Integrated nutrient management } \\
\hline $\mathrm{SE} \pm$ & 1.78 & 1.59 & 1.68 & 1.23 & 0.78 & 1.00 & 1.16 & 1.24 & 1.20 & 0.51 & 0.57 & 0.54 & 0.05 & 0.03 & 0.04 \\
\hline $\mathrm{LSD}_{0.05}$ & 5.08 & 4.60 & 4.84 & 3.51 & 2.23 & 2.87 & 3.44 & 3.73 & 3.58 & NS & NS & NS & NS & NS & NS \\
\hline \multicolumn{16}{|c|}{ Integrated nutrient management $\times$ Crop establishment methods } \\
\hline $\mathrm{SE} \pm$ & 6.59 & 5.86 & 6.22 & 5.65 & 3.28 & 4.46 & 5.73 & 6.35 & 6.04 & 2.58 & 2.66 & 2.62 & 0.27 & 0.23 & 0.25 \\
\hline $\mathrm{LSD}_{0.05}$ & 19.09 & 18.80 & 8.94 & 16.12 & 9.36 & 12.74 & 16.34 & 18.12 & 17.23 & NS & NS & NS & NS & NS & NS \\
\hline
\end{tabular}

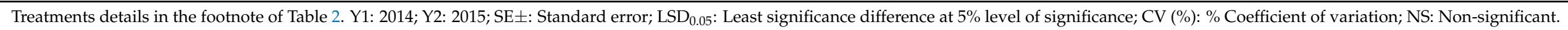


3.3. Crop and Water Productivity Are Influenced by Crop Establishment Methods and Integrated Nutrient Management

\subsubsection{Effect of Crop Establishment Methodologies}

The highest grain yield $\left(6.21 \mathrm{t} \mathrm{ha}^{-1}\right)$, straw yield $\left(7.50 \mathrm{t} \mathrm{ha}^{-1}\right)$ and total biomass yield $\left(13.88 \mathrm{t} \mathrm{ha}^{-1}\right)$ of rice were noted under SRI that was significantly higher as compared to aerobic culture but at par with conventional flooded rice culture (Table 4 ). The grain yield of rice under aerobic culture was $24.6 \%$ lower than SRI, whereas the magnitude of reduction was $20.9 \%$ as compared to that registered under flooded rice culture. Conventional flooded rice produced $4.67 \%$ lower crop productivity than that recorded under the system of rice intensification. Crop efficiency factor in terms of harvest index or migration co-efficient followed a similar trend as that of crop productivity.

Concerning the irrigation water productivity and total water productivity, aerobic rice culture proved to be significantly superior as compared to other crop production methodologies like flooded culture and system of rice intensification. Maximum irrigation

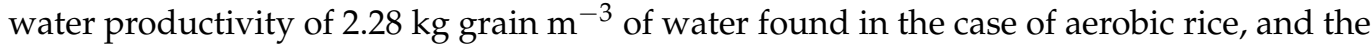

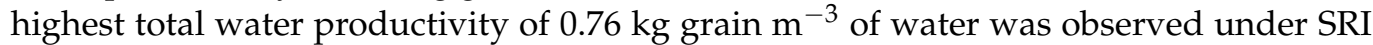
which was considerably higher than that recorded under conventional flooded rice, where irrigation water productivity and total water productivity were only $1.72 \mathrm{~kg}_{\text {grain m}}{ }^{-3}$ of

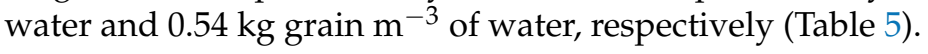

\subsubsection{Effect of Integrated Nutrient Management}

The interaction effect revealed that the highest crop productivity of $6.20 \mathrm{tha}^{-1}$ was achieved under the plant nutrient management treatment where 75\% RDN applied through chemical fertilizer was integrated with $25 \%$ RDN through vermicompost $\left(\mathrm{F}_{4}\right)$ that immediately followed the INM treatment where 50\% RDN through chemical fertilizer was integrated with $25 \%$ RDN supplied through vermicompost together with brown manuring and bio-fertilizer $\left(\mathrm{F}_{8}\right)$ (Table 4 ). These two treatments improved crop productivity of $4.03 \%$ and $2.68 \%$, respectively, over the productivity recorded under the treatment that received plant nutrition solely through chemical fertilizer. Crop efficiency factor, i.e., harvest index recorded under integrated nutrient management treatments was higher as compared to plant nutrition supplied solely through chemical sources. Aerobic culture always produced less crop productivity as compared to flooded rice and the SRI under nutrient management treatments. The highest irrigation water productivity and total water productivity of $2.25 \mathrm{~kg}$

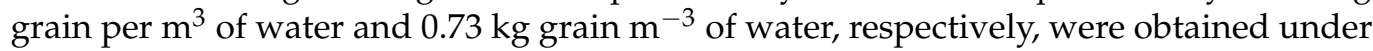
the integrated nutrient management treatment that recorded the highest crop productivity $\left(\mathrm{F}_{4}\right)$. Significantly higher water productivities were recorded under nutrient management treatments over absolute control (Table 5).

\subsection{Crop Establishment Methods and Integrated Nutrient Management Influenced the Profitability of Rice}

As revealed from Table 6, the highest gross returns, net returns in terms of Indian currency of Rs. 100,683 ha ${ }^{-1}$ and Rs. $67,049 \mathrm{ha}^{-1}$ respectively, and benefit-cost ratio (1.99) were accrued from the SRI and was significantly higher over aerobic culture and conventional flooded rice. Value cost ratio was significantly higher (9.04) under SRI compared to aerobic rice methodology, but remained at par with the conventional flooded situation. Partial factor productivity of nutrients (13.90) recorded under the SRI was significantly higher when compared with both the aerobic culture and conventional flooded rice. 
Table 4. Crop establishment methods and integrated nutrient management influenced the productivity of rice.

\begin{tabular}{|c|c|c|c|c|c|c|c|c|c|c|c|c|}
\hline \multirow{2}{*}{ Treatments } & \multicolumn{3}{|c|}{ Grain Yield (t ha ${ }^{-1}$ ) } & \multicolumn{3}{|c|}{ Straw Yield $\left(\mathrm{t} \mathrm{ha}^{-1}\right)$} & \multicolumn{3}{|c|}{ Total Biomass Yield (t ha ${ }^{-1}$ ) } & \multicolumn{3}{|c|}{ Harvest Index (\%) } \\
\hline & Y1 & $\mathrm{Y} 2$ & Mean & Y1 & Y2 & Mean & Y1 & Y2 & Mean & Y1 & $\mathrm{Y} 2$ & Mean \\
\hline \multicolumn{13}{|c|}{ Crop Establishment Methods } \\
\hline $\mathrm{T}_{2}$ & 6.26 & 6.17 & 6.21 & 7.50 & 7.78 & 7.64 & 13.79 & 13.97 & 13.88 & 45.39 & 44.16 & 44.77 \\
\hline $\mathrm{T}_{3}$ & 5.96 & 5.88 & 5.92 & 7.28 & 7.46 & 7.37 & 13.28 & 13.36 & 13.32 & 44.88 & 44.01 & 44.44 \\
\hline $\mathrm{SE} \pm$ & 0.12 & 0.09 & 0.10 & 0.23 & 0.18 & 0.20 & 0.24 & 0.26 & 0.25 & 0.19 & 0.30 & 0.24 \\
\hline $\mathrm{LSD}_{0.05}$ & 0.47 & 0.37 & 0.42 & 0.90 & 0.70 & 0.80 & 0.94 & 0.98 & 0.96 & 0.74 & 1.18 & 0.96 \\
\hline \multicolumn{13}{|c|}{ Integrated Nutrient Management } \\
\hline $\mathrm{F}_{1}$ & 3.63 & 3.49 & 3.56 & 5.66 & 5.93 & 5.79 & 9.33 & 9.46 & 9.39 & 38.91 & 36.89 & 37.90 \\
\hline $\mathrm{F}_{2}$ & 5.91 & 6.01 & 5.96 & 7.46 & 7.77 & 7.61 & 13.41 & 13.83 & 13.62 & 44.07 & 43.45 & 43.76 \\
\hline $\mathrm{F}_{3}$ & 5.96 & 6.05 & 6.00 & 7.18 & 7.44 & 7.31 & 13.17 & 13.52 & 13.34 & 45.25 & 44.75 & 45.00 \\
\hline $\mathrm{F}_{4}$ & 6.30 & 6.10 & 6.20 & 7.46 & 7.58 & 7.52 & 13.77 & 13.70 & 13.73 & 45.75 & 44.52 & 45.13 \\
\hline $\mathrm{F}_{5}$ & 5.57 & 5.47 & 5.52 & 6.88 & 7.07 & 6.97 & 12.46 & 12.57 & 12.51 & 44.70 & 43.52 & 44.11 \\
\hline $\mathrm{F}_{6}$ & 5.65 & 5.58 & 5.61 & 6.95 & 7.22 & 7.08 & 12.62 & 12.82 & 12.72 & 44.77 & 43.52 & 44.14 \\
\hline $\mathrm{F}_{7}$ & 5.89 & 5.80 & 5.84 & 7.03 & 7.27 & 7.15 & 12.95 & 13.09 & 13.02 & 45.48 & 44.31 & 44.89 \\
\hline $\mathrm{SE} \pm$ & 0.13 & 0.10 & 0.11 & 0.06 & 0.04 & 0.05 & 0.15 & 0.13 & 0.14 & 0.20 & 0.21 & 0.20 \\
\hline $\mathrm{LSD}_{0.05}$ & 0.39 & 0.27 & 0.33 & 0.16 & 0.14 & 0.20 & 0.44 & 0.38 & 0.41 & 0.57 & 0.61 & 0.59 \\
\hline CV $(\%)$ & 7.4 & 5.9 & 6.6 & 9.0 & 8.2 & 8.6 & 5.7 & 6.0 & 5.8 & 7.0 & 8.5 & 7.70 \\
\hline \multicolumn{13}{|c|}{ Interaction } \\
\hline \multicolumn{13}{|c|}{ Crop establishment methods $\times$ Integrated nutrient management } \\
\hline $\mathrm{SE} \pm$ & 0.05 & 0.03 & 0.04 & 0.08 & 0.06 & 0.07 & 0.07 & 0.06 & 0.06 & 0.11 & 0.13 & 0.12 \\
\hline $\mathrm{LSD}_{0.05}$ & 0.15 & 0.10 & 0.12 & 0.23 & 0.20 & 0.21 & 0.20 & 0.18 & 0.19 & NS & NS & NS \\
\hline \multicolumn{13}{|c|}{ Integrated nutrient management $\times$ Crop establishment methods } \\
\hline $\mathrm{SE} \pm$ & 0.24 & 0.16 & 0.20 & 0.09 & 0.10 & 0.09 & 0.26 & 0.23 & 0.24 & 0.34 & 0.37 & 0.35 \\
\hline $\mathrm{LSD}_{0.05}$ & 0.69 & 0.45 & 0.57 & 0.30 & 0.34 & 0.32 & 0.76 & 0.66 & 0.71 & NS & NS & NS \\
\hline
\end{tabular}

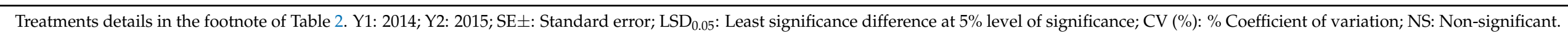


Table 5. Crop establishment methods and integrated nutrient management influenced the irrigation water input and water productivity of rice

\begin{tabular}{|c|c|c|c|c|c|c|c|c|c|c|c|c|}
\hline \multirow{2}{*}{ Treatments } & \multicolumn{3}{|c|}{$\begin{array}{l}\text { Irrigation Water Input } \\
\left(\mathrm{m}^{3} \text { of Water }\right)\end{array}$} & \multicolumn{3}{|c|}{$\begin{array}{l}\text { Total Water Input } \\
\left(\mathrm{m}^{3} \text { of Water }\right)\end{array}$} & \multicolumn{3}{|c|}{$\begin{array}{l}\text { Irrigation Water Productivity } \\
\text { (kg Grain } \mathrm{m}^{-3} \text { of Water) }\end{array}$} & \multicolumn{3}{|c|}{$\begin{array}{l}\text { Total Water Productivity } \\
\text { (kg Grain } \mathrm{m}^{-3} \text { Water) }\end{array}$} \\
\hline & Y1 & Y2 & Mean & Y1 & $\mathrm{Y} 2$ & Mean & Y1 & $\mathrm{Y} 2$ & Mean & Y1 & Y2 & Mean \\
\hline \multicolumn{13}{|c|}{ Crop Establishment Methods } \\
\hline $\mathrm{T}_{1}$ & 2400 & 1800 & 2100 & 6409 & 6774 & 6592 & 1.9 & 2.66 & 2.28 & 0.71 & 0.73 & 0.72 \\
\hline $\mathrm{T}_{2}$ & 3200 & 2400 & 2800 & 7920 & 8252 & 4521 & 1.95 & 2.57 & 2.26 & 0.79 & 0.74 & 0.76 \\
\hline $\mathrm{T}_{3}$ & 4000 & 3000 & 3500 & 10,602 & 11,193 & 10,898 & 1.49 & 1.96 & 1.72 & 0.56 & 0.52 & 0.54 \\
\hline $\mathrm{SE} \pm$ & & & & & & & 0.11 & 0.06 & 0.08 & 0.01 & 0.007 & 0.008 \\
\hline CV $(\%)$ & & & & & & & 16 & 10.4 & 13.2 & 13.0 & 8.2 & 10.6 \\
\hline \multicolumn{13}{|c|}{ Integrated Nutrient Management } \\
\hline $\mathrm{F}_{1}$ & 3200 & 2400 & 2800 & 8310 & 8740 & 8525 & 1.13 & 1.45 & 1.29 & 0.43 & 0.40 & 0.41 \\
\hline $\mathrm{F}_{2}$ & 3200 & 2400 & 2800 & 8310 & 8740 & 8525 & 1.85 & 2.50 & 2.17 & 0.71 & 0.69 & 0.70 \\
\hline $\mathrm{F}_{3}$ & 3200 & 2400 & 2800 & 8310 & 8740 & 8525 & 1.86 & 2.52 & 2.19 & 0.72 & 0.70 & o.71 \\
\hline $\mathrm{F}_{4}$ & 3200 & 2400 & 2800 & 8310 & 8740 & 8525 & 1.96 & 2.54 & 2.25 & 0.76 & 0.70 & 0.73 \\
\hline $\mathrm{F}_{5}$ & 3200 & 2400 & 2800 & 8310 & 8740 & 8525 & 1.74 & 2.28 & 2.01 & 0.67 & 0.62 & 0.64 \\
\hline $\mathrm{F}_{6}$ & 3200 & 2400 & 2800 & 8310 & 8740 & 8525 & 1.76 & 2.32 & 2.04 & 0.68 & 0.64 & 0.66 \\
\hline $\mathrm{SE} \pm$ & & & & & & & 0.15 & 0.06 & 0.10 & 0.02 & 0.009 & 0.014 \\
\hline $\mathrm{LSD}_{0.05}$ & & & & & & & 0.43 & 0.17 & 0.30 & 0.8 & 0.02 & 0.05 \\
\hline CV $(\%)$ & & & & & & & 13.1 & 7.0 & 10.0 & 9.5 & 6.4 & 7.9 \\
\hline \multicolumn{13}{|c|}{ Interaction } \\
\hline \multicolumn{13}{|c|}{ Crop establishment methods $\times$ Integrated nutrient management } \\
\hline $\mathrm{SE} \pm$ & & & & & & & 0.05 & 0.02 & 0.03 & 0.007 & 0.003 & 0.005 \\
\hline $\mathrm{LSD}_{0.05}$ & & & & & & & NS & NS & NS & NS & NS & NS \\
\hline \multicolumn{13}{|c|}{ Integrated nutrient management $\times$ Crop establishment methods } \\
\hline $\mathrm{SE} \pm$ & & & & & & & 0.26 & 0.10 & 0.18 & 0.031 & 0.014 & 0.022 \\
\hline $\mathrm{LSD}_{0.05}$ & & & & & & & NS & NS & NS & NS & NS & NS \\
\hline
\end{tabular}

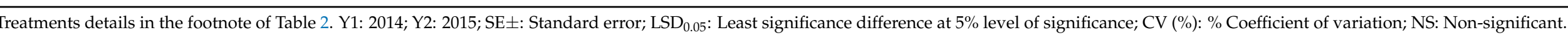


Table 6. Crop establishment methods and integrated nutrient management influenced the profitability of rice.

\begin{tabular}{|c|c|c|c|c|c|c|c|c|c|c|c|c|c|c|c|}
\hline \multirow{2}{*}{ Treatments } & \multicolumn{3}{|c|}{ Gross Returns (Rs ha ${ }^{-1}$ ) } & \multicolumn{3}{|c|}{ Net Returns (Rs ha ${ }^{-1}$ ) } & \multicolumn{3}{|c|}{ Benefit-Cost Ratio } & \multicolumn{3}{|c|}{ Value Cost Ratio } & \multicolumn{3}{|c|}{ Partial Factor Productivity } \\
\hline & Y1 & Y2 & Mean & Y1 & Y2 & Mean & Y1 & Y2 & Mean & Y1 & Y2 & Mean & Y1 & Y2 & Mean \\
\hline \multicolumn{16}{|c|}{ Crop Establishment Method } \\
\hline $\mathrm{T}_{2}$ & 98,186 & 103,179 & 100,683 & 66,023 & 68,074 & 67,049 & 2.05 & 1.94 & 1.99 & 9.25 & 8.84 & 9.04 & 14.00 & 13.80 & 13.90 \\
\hline $\mathrm{T}_{3}$ & 93,749 & 98,524 & 96,136 & 57376 & 59,209 & 58,293 & 1.58 & 1.50 & 1.54 & 8.83 & 8.13 & 8.48 & 13.33 & 13.15 & 13.24 \\
\hline $\mathrm{SE} \pm$ & 556.3 & 316.3 & 436.3 & 556.3 & 316.3 & 436.3 & 0.017 & 0.011 & 0.014 & 0.33 & 0.20 & 0.26 & 0.09 & 0.04 & 0.06 \\
\hline $\mathrm{LSD}_{0.05}$ & 2184.3 & 1241.9 & 1713.1 & 2184.3 & 1241.9 & 1713 & 0.07 & 0.042 & 0.056 & 1.29 & 0.78 & 1.03 & 0.36 & 0.16 & 0.26 \\
\hline \multicolumn{16}{|c|}{ Integrated Nutrient Management } \\
\hline $\mathrm{F}_{1}$ & 59,216 & 61,543 & 60,380 & 31,152 & 31,413 & 31,283 & 1.11 & 1.04 & 1.07 & & & & & & \\
\hline $\mathrm{F}_{2}$ & 93,356 & 100,903 & 97130 & 61,306 & 66,686 & 63,996 & 1.91 & 1.95 & 1.93 & 7.58 & 8.46 & 8.02 & 12.05 & 12.25 & 12.15 \\
\hline $\mathrm{F}_{3}$ & 93,549 & 100,380 & 96,965 & 60,154 & 64,418 & 62,286 & 1.80 & 1.79 & 1.79 & 8.52 & 9.20 & 8.86 & 13.33 & 13.53 & 13.43 \\
\hline $\mathrm{F}_{4}$ & 98,660 & 101,776 & 100,218 & 65,865 & 66,614 & 66,240 & 2.01 & 1.89 & 1.95 & 9.22 & 9.91 & 9.56 & 14.09 & 13.64 & 13.86 \\
\hline $\mathrm{F}_{5}$ & 87,723 & 91,833 & 89,778 & 52,940 & 53,376 & 53,158 & 1.52 & 1.39 & 1.45 & 8.89 & 7.95 & 8.42 & 13.80 & 13.55 & 13.67 \\
\hline $\mathrm{F}_{6}$ & 88,933 & 93,696 & 91,314 & 55,350 & 56,839 & 56,095 & 1.65 & 1.54 & 1.59 & 9.46 & 8.32 & 8.89 & 13.99 & 13.82 & 13.90 \\
\hline $\mathrm{F}_{7}$ & 92,336 & 96,902 & 94,619 & 57,493 & 58,045 & 57,769 & 1.65 & 1.49 & 1.57 & 10.29 & 9.23 & 9.76 & 14.59 & 14.37 & 14.48 \\
\hline $\mathrm{SE} \pm$ & 670.4 & 473.4 & 571.9 & 670.4 & 473.4 & 571.9 & 0.021 & 0.014 & 0.017 & 0.21 & 0.12 & 0.16 & 0.11 & 0.08 & 0.09 \\
\hline $\mathrm{LSD}_{0.05}$ & 1913.4 & 1351.1 & 1632.2 & 1913.4 & 1351.1 & 1632.2 & 0.059 & 0.039 & 0.049 & 0.60 & 0.35 & 0.47 & 0.31 & 0.22 & 0.26 \\
\hline CV $(\%)$ & 10.3 & 10.5 & 10.4 & 13.6 & 11.5 & 12.5 & 5.8 & 6.6 & 6.2 & 7.8 & 4.7 & 6.2 & 5.6 & 6.9 & 6.2 \\
\hline \multicolumn{16}{|c|}{ Interaction } \\
\hline \multicolumn{16}{|c|}{ Crop establishment methods $\times$ Integrated nutrient management } \\
\hline $\mathrm{SE} \pm$ & 249.1 & 169.3 & 209.2 & 249.1 & 169.3 & 209.2 & 0.008 & 0.005 & 0.006 & 0.09 & 0.06 & 0.07 & 0.04 & 0.07 & 0.05 \\
\hline $\operatorname{LSD}_{0.05}$ & 710.9 & 483.3 & 597.1 & 710.9 & 483.3 & 597.1 & 0.022 & 0.014 & 0.018 & 0.28 & 0.16 & 0.22 & 0.14 & 0.12 & 0.13 \\
\hline \multicolumn{16}{|c|}{ Integrated nutrient management $\times$ Crop establishment methods } \\
\hline $\mathrm{SE} \pm$ & 1161.2 & 819.9 & 990.5 & 1161.2 & 819.9 & 990.5 & 0.036 & 0.024 & 0.030 & 0.36 & 0.21 & 0.28 & 0.20 & 0.13 & 0.16 \\
\hline $\mathrm{LSD}_{0.05}$ & 3314.2 & 2340.2 & 2827.2 & 3314.2 & 2340.2 & 2827 & 0.103 & 0.069 & 0.086 & 1.04 & 0.61 & 0.82 & 0.54 & 0.38 & 0.46 \\
\hline
\end{tabular}

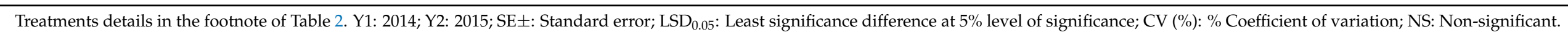


Among nutrient management treatments, $\mathrm{F}_{4}$ that substituted $25 \% \mathrm{RDN}$ through vermicompost fetched maximum gross returns in terms of Indian currency (Rs. 100,218 ha $^{-1}$ ), net returns (Rs. $66,240 \mathrm{ha}^{-1}$ ) and benefit-cost ratio of 1.95. Plant nutrients supplied totally through chemical fertilizer $\left(\mathrm{F}_{2}\right)$ were recorded statistically at par benefit-cost ratio (1.93) and this treatment immediately followed INM treatment $F_{4}$. The rest of the integrated nutrient management treatments had significantly lower benefit-cost ratios under the experiment whereas value-cost ratio and partial factor productivity of nutrients were highest under integrated nutrient management treatments where the major portion (50\%) of the RDN was substituted by organic sources of nutrients and bio-fertilizer. Partial factor productivity of nutrients was significantly lower under the treatment having $100 \%$ RDF totally through chemical sources as compared to INM treatments. Interaction effects of crop establishment methodologies and integrated nutrient management were found to be significant in relation to the gross returns, net returns, benefit-cost ratio, value cost ratio and partial productivity of nutrients.

\section{Discussion}

Water is the most important critical input for the production of rice. Conventionally grown flooded rice requires on an average $1500 \mathrm{~mm}$ of water depending on water management, edaphic and climatic factors. Interestingly, the production of even 1 kilogram of rice requires approximately 3000-5000 L of water input. Since time immemorial, an abundance of water received from monsoon rains as endowed by nature under the Indo-Gangetic Plain zone of West Bengal, India, allowed successful rice cultivation without interruption during the wet season without the application of additional irrigation input. Of late, due to global climate change, the effect of El-Nino, La-Nina, Asian blue Cloud and other weather aberration monsoons has become irregular and distribution of rainfall has become erratic which compel the farmers in this region to apply additional irrigation water for rice production entailing higher cost. Moreover, the adverse impact of the environment and ecological consequences of conventional flooded rice culture like nitrate and chromium toxicity, arsenic contamination in groundwater in the Indo-Gangetic Plain Zone (IGP) of the country, sometimes referred to as the biggest arsenic calamity in the world, have further aggravated the problem of rice production sustenance and stability in this region [8]. The introduction of water-saving and water-wise alternative rice production methods under this region for maximizing water productivity to produce more crops utilizing every drop of water is becoming of utmost importance in this region for rice production sustainability. Moreover, suitable integrated nutrient management practices utilizing locally available low-cost bio-resources and exploring the benefit of brown manuring under water-saving rice culture for enhancement of crop and water productivity and improving soil quality is of utmost priority in research in this region. Against such a backdrop, to address the issues cited earlier, the present study has included different rice production methodologies such as aerobic culture, SRI and conventional flooded rice culture and on other hand to evaluate the performance of integrated plant nutrition management treatments involving brown manuring, bio-fertilizer as well as locally available bio-resources like farmyard manure and vermicompost.

As envisaged in the present study, the rice grain productivity under SRI was $24.6 \%$ higher over aerobic culture and $4.67 \%$ higher over conventional rice culture. The lowest crop productivity, yield penalty and crop efficiency factor as recorded in an aerobic situation have been reported by researchers like Bouman et al. [39], Peng et al. [40] and Patel et al. [6]; whereas, enhancement in crop productivity under SRI has been supported by Uphoff et al. [14], Kassam et al. [15]; Ceesay [16] and Chapagain et al. [41]. Interestingly, both irrigation water productivity and total water productivity was significantly higher under aerobic culture as compared to flooded rice and the system of rice intensification. The basic driving force of aerobic rice culture is its water economy sacrificing some productivity. The total water productivity under this crop culture improved from $0.54 \mathrm{~kg}_{\text {grain }} \mathrm{m}^{-3}$ of

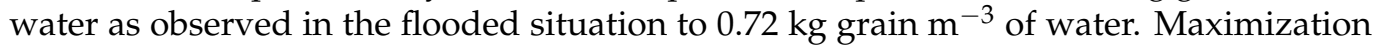


in water productivity under aerobic culture was earlier reported by Belder et al. [42] and Chan et al. [13]. In spite of its significant role in the water economy, yield penalty under this crop culture has depreciated and outweighs the benefit of water savings quality; by contrast, the SRI has proved to be an environmentally benign water-saving production methodology in terms of both crop and water productivity without compromising yield rather yield advantage among the crop cultures in the study. The highest crop productivity and crop efficiency as achieved under integrated plant nutrition were owing to better availability of plant nutrients under rational use of chemical fertilizer, organic manures and bio-fertilizer. Chapagain et al. [41] reported a greater harvest index in rice under organic treatments compared to inorganic management. Yield advantage as achieved under integrated plant nutrition in the system of rice intensification was due to better biotic activities in and around the root zone, proper soil aeration, enhanced mobilization of water and nutrients to aerial parts and translocation of photosynthates to the source of the sink, which corroborate with earlier researches $[17,43]$. Among the growth attributes studied, total root biomass was significantly lower in aerobic culture owing to a reduction in root biomass in surface layer [44] and adaptation by changing in rooting pattern to that of dryland crops, which are attributable to the considerable reduction in adventitious root number and lesser root weight density [45]. Higher root biomass in flooded rice recorded up to flowering may be attributable to surface soil under this crop culture being crowded with fine roots that form a fibrillate mat in flooded culture and a sub-surface showing sparse rooting [46]; and rice has a unique characteristic in root morphology and anatomy with suitability under flooded conditions, inclusive of the development of aerenchyma and a compact root system. However, remarkably lower root biomass under flooded rice as compared to that recorded in SRI during harvest stage was due to degeneration of roots after flowering in flooded culture by water congestion as reported by lida et al. [47] and Mahender Kumar et al. [48]. The plots receiving integrated plant nutrient treatments exhibited higher root biomass over the plot that received $100 \%$ recommended dose of fertilizer through a sole chemical may be due to better biotic activities within the rhizosphere in the presence of organic inputs and bio-fertilizer resulting in proper growth and proliferation of roots. The same feature was found in the case of total dry matter production by the crop. Integrated use of bio-fertilizer with brown manuring, vermicompost and application of chemical fertilizer exhibited synergistic action in relation to plant nutrition reflected in uniform germination, faster growth, increased dry matter content and physiological and biochemical attributes like chlorophyll content, carotenoids, soluble protein, sugar and photosynthetic rate as revealed from the study of Kannan and Ponmurugan [49] that ultimately led to better crop productivity. Advancement in physiological attributes such as early flowering and maturity under aerobic culture may be due to quicker establishment of a crop under a direct-seeded aerobic situation escaping transplanting shock that was not avoided by a transplanted crop.

Among the yield attributes assessed, the number of productive tillers per unit area, total spikelets and filled spikelets, ripening ratio was higher under the system of rice intensification due to wider spacing that favoured a better micro-climate providing ample light intensity and larger soil volume encouraging luxurious growth of roots and tillers. The lowest number of productive tillers as reported under aerobic culture was due to the mortality of tillers due to stress. In spite of the highest tillers production under conventional flooded culture, productive tillers were relatively lower under this crop culture and that may be due to interspecific competition under crowded crop geometry leading to tillers mortality. In other research reports, the higher number of filled grains per panicle and lower spikelet sterility under SRI is also documented [50]. Although 1000-grain weight was higher under conventional flooded culture but did not vary significantly with SRI.

It is worth mentioning that the practical feasibility of implementation of any production methodology in a crop or crop sequence depends on economic profitability and sustainability for ensuring food security. As rice is a staple food crop in the Indo-Gangetic Plain zone of India, rice production cannot be sacrificed at the cost of the water economy 
alone. The highest economic profitability under SRI has been achieved with two integrated nutrient management practices. Relatively lower economics of production as reported under some integrated plant nutrient management options under different rice production methodologies as compared to the sole application of chemical fertilizer being due to the requirement of a huge quantity of organic inputs and higher cost of production of organic sources of nutrients, as reported by Ranjitha et al. [51]. Partial factor productivity of applied nutrients provides an idea about economic output relative to the utilization of all nutrient sources and value cost ratio is a measure that represents the return on the money invested in fertilizer. Partial factor productivity was higher under the system of rice intensification and all the integrated plant nutrition methods irrespective of crop production methodologies recorded numerically higher partial factor productivities over sole application of chemical fertilizer indicated better economic output, economic use of fertilizer and better utilization of all nutrients under the treatments. Generally, a value cost ratio greater numerically than 2.0 according to Amanullah and Lal [52], is an indication of total monetary return on the money invested in fertilizer. A higher value cost ratio as observed under the system of rice intensification and integrated plant nutrition indicated rational use of nutrients and economic use of fertilizer under the treatments concerned. This is an indication of fertilizer management in an integrated manner with due emphasis on appropriate production methodology, a best management practice so that even resource-poor farmers can afford rice production with low-cost methodology and limited resources using a water-wise alternative rice production methodology. For fine-tuning of the results, separate integrated nutrient management strategies need to be designed for each crop culture, as nutrient uptake, availability, and dynamics are drastically influenced due to change in soil redox under different water regimes under alternative rice production methodologies compared to traditional flooded culture. There is an urgent need to study the standardization of integrated crop management strategies for alternative rice production methodologies in the Indo-Gangetic plain zone for sustainable rice production with ecological footprints under the scenario of a shrinking resource base.

The present study has been conducted taking into consideration of a specific variety 'CR Dhan 304' and there is scope for testing other varieties because the performance varies under different establishment methods. For example, varieties bred specifically for aerobic rice cultivation may perform better under aerobic conditions, while other varieties may not. The crop establishment method is highly situation- and location-specific and IGP indicates a vast rice grown area. Under IGP, multilocational trials with different varieties can be conducted for the micro-situation specific recommendations of established methods. The skill and technical know-how of the labourers and availability of farm machinery are important for uniform stand establishment under SRI. In the case of INM, the availability of quality manures and biofertilizers may be a constraint. Furthermore, some more locally available nutrient sources may be tested.

\section{Conclusions}

In the light of the above findings, it can be concluded that under the agro-climatic situation of the Indo-Gangetic Plain Zone of West Bengal, India, rice productivity and economic profitability can be improved under the system of rice intensification. Integration of $75 \%$ RDN through chemical fertilizer and substitution of $25 \%$ RDN through vermicompost followed by $50 \%$ RDN through chemicals, $25 \%$ RDN through vermicompost, and brown manuring coupled with the application of bio-fertilizer Azospirillium brassilense was the best-integrated plant nutrition package for yield enhancement of rice under both aerobic, system of rice intensification (SRI) and conventional flooded culture for better growth and yield attributes, crop and water productivity and economic profitability. Although aerobic rice culture recorded maximum water productivity, the yield penalty was $24.6 \%$. Conventional flooded rice registered very low water productivity as compared to aerobic culture and SRI and yield potential was also lower than SRI. However, for promoting 
water-saving rice methodologies suitable genotypes that may be adapted in the irrigated ecology along with integrated crop management strategies should be screened.

Author Contributions: Conceptualization: A.M., B.K.S., J.K.D., S.M., S.P. and D.J.G.; methodology: A.M., B.K.S. and J.K.D.; formal analysis: A.M., S.M. and A.H.; data curation: A.M., S.M. and A.H.; statistical expertise: A.M., S.M. and A.H.; writing—original draft preparation: A.M., B.K.S., J.K.D., S.P. and D.J.G.; writing-review and editing: S.M., A.G., W.F.A. and A.H.; visualization: A.M., B.K.S., J.K.D.; supervision: B.K.S.; project administration: B.K.S., A.G., W.F.A. and A.H.; funding acquisition: B.K.S., A.G., W.F.A. and A.H. All authors have read and agreed to the published version of the manuscript.

Funding: This research was funded by the Taif University Researchers Supporting Project number (TURSP-2020/53), Taif University, Taif, Saudi Arabia for funding the research.

Data Availability Statement: The data that support the findings of this study are available from the corresponding authors upon reasonable request.

Acknowledgments: The authors also extend their appreciation to the Taif University Researchers Supporting Project number (TURSP-2020/53), Taif University, Taif, Saudi Arabia for funding the research.

Conflicts of Interest: The authors declare no conflict of interest.

$\begin{array}{ll}\text { Abbreviations } \\ \text { CTR: } & \text { Conventional flooded transplanted rice } \\ \text { DAT: } & \text { Days after transplanting } \\ \text { DSR: } & \text { Direct seeded rice } \\ \text { FYM: } & \text { Farmyard manure } \\ \text { INM: } & \text { Integrated nutrient management } \\ \text { PFP: } & \text { Partial factor productivity of nutrients } \\ \text { RDF: } & \text { Recommended dose of fertilizer } \\ \text { RDN: } & \text { Recommended dose of nitrogen } \\ \text { SRI: } & \text { System of rice intensification } \\ \text { TDM: } & \text { Total dry matter } \\ \text { VCR: } & \text { Value Cost Ratio }\end{array}$

\section{References}

1. Ram, M.S.; Shankar, T.; Maitra, S.; Adhikary, R.; Swamy, G.V.V.S.N. Productivity, nutrient uptake and nutrient use efficiency of summer rice (Oryza sativa) as influenced by integrated nutrient management practices. Crop Res. 2020, 55, 65-72. [CrossRef]

2. Yu, S.; Ali, J.; Zhang, C.; Li, Z.; Zhang, Q. Genomic breeding of green super rice varieties and their deployment in Asia and Africa. Theor. Appl. Genet. 2020, 133, 1427-1442. [CrossRef]

3. Srivastava, A.K.; Singh, S.; Dar, M.H.; Sing, U.S. Stress-Tolerant Rice Varieties and Conforming Management Practices for intensification of rain-fed eco-system in India. SATSA Mukhapatra-Annu. Tech. Issue 2016, 20, 1-14.

4. FAO. The Future of Food and Agriculture: Alternative Pathways to 2050; Food and Agriculture Organization of the United Nations: Rome, Italy, 2016; p. 228.

5. Mbow, C.; Rosenzweig, C.; Barioni, L.G.; Benton, T.G.; Herrero, M.; Krishnapillai, M.; Liwenga, E.; Pradhan, P.; Rivera-Ferre, M.G.; Sapkota, T.; et al. Food Security. In Climate Change and Land: An IPCC Special Report on Climate Change, Desertification, Land Degradation Sustainable Land Management, Food Security, and Greenhouse Gas Fluxes in Terrestrial Ecosystems; Shukla, P.R., Skea, J., Calvo Buendia, E., Masson-Delmotte, V., Pörtner, H.-O., Roberts, D.C., Zhai, P., Slade, R., Connors, S., van Diemen, R., et al., Eds.; Intergovernmental Panel on Climate Change: Geneva, Switzerland, 2019; pp. 437-550, in press.

6. Patel, D.P.; Das, A.; Munda, G.C.; Ghosh, P.K.; Bordoloi, J.S.; Kumar, M. Evaluation of yield and physiological attributes of high yielding varieties under aerobic and flood- irrigated management practices in mid-hills ecosystem. Agric. Water Manag. 2010, 97, 1269-1276. [CrossRef]

7. Lal, B.; Gautam, P.; Joshi, E. Different rice establishment methods for producing more rice per drop of water: A review. Int. J. Res. Biosci. 2013, 2, 1-12.

8. Midya, A.; Saren, B.K.; Pramanik, K. Aerobic rice culture, System of Rice Intensification (SRI) and System of Assured Rice Production (SARP): Emerging water savings production technologies for rice yield stability in tropics under shrinking water resource base. In Proceedings of the Souvenir Paper of 1st International Conference on Bio-Resource, Environment and Agricultural Sciences, Visva-Bharati, West Bengal, India, 4-6 February 2017; pp. 61-66.

9. Katsura, K.; Okami, M.; Mizunuma, H.; Kato, Y. Radiation use efficiency, N accumulation and biomass production of high-yielding rice in aerobic culture. Field Crops Res. 2010, 117, 81-89. [CrossRef] 
10. Rajkumar, D.; Subramanian, E.; Ramesh, T.; Maragatham, N.; Martin, G.J.; Thiyagarajan, G. Striding towards aerobic rice cultivation- A review. Agric. Rev. 2009, 30, 213-218.

11. Lampayan, R.M.; Bouman, B.A.M.; De Dios, J.L.; Espiritu, A.J.; Soriano, J.B.; Lactaoen, A.T.; Faronilo, J.E.; Thant, K.M. Yield of aerobic rice in rainfed lowlands of the Philippines as affected by nitrogen management and row spacing. Field Crops Res. 2010, 116, 165-174. [CrossRef]

12. Vial, L.K. Aerobic and Alternate-Wet-and-Dry (AWD) Rice Systems. A Report for Nuffield Australis Farming Scholars. Nuffield Australia, Project No: RABO 090, Rabobank, Tooranie, Tooranie Road via Swan Hill, Vic, 3585 Nuffield Australia, 45.2007. Available online: https://www.nuffieldscholar.org/sites/default/files/reports/2006_AU_Leigh-Vial_Aerobic-And-AlternateWet-And-Dry-Awd-Rice-Systems.pdf (accessed on 15 August 2021).

13. Chan, C.S.; Zainudin, H.; Saad, A.; Azmi, M. Productive water use in aerobic rice cultivation. J. Trop. Agric. Food Sci. 2012, 49, 117-126.

14. Uphoff, N. Possible explanations for the productivity gains achieved with the System of Rice Intensification (SRI). Transitions in Agriculture for Enhancing Water Productivity. In Proceedings of the International Symposium, Killikulam, Tamil Nadu, India, 23-25 September 2003.

15. Kassam, A.; Stoop, W.; Uphoff, N. Review of SRI modifications in rice crop and water management and research issues for making further improvements in agricultural and water productivity. Paddy Water Environ. 2011, 9, 163-180. [CrossRef]

16. Ceesay, M. An opportunity for increasing factor productivity for rice cultivation in the Gambia through SRI. Paddy Water Environ. 2011, 9, 129-135. [CrossRef]

17. Zhao, I.M.; Wu, L.H.; Li, Y.S.; Animesh, S.; Zhu, D.F.; Uphoff, N. Comparison of yield, water use efficiency, and soil microbial biomass as affected by system of rice intensification. Commun. Soil Sci. Plant Anal. 2010, 41, 1-12. [CrossRef]

18. Kumar, R.M.; Tuti, M.D.; Sreedevi, B.; Surekha, K.; Babu, V.R. Rice Agronomy: Towards improving productivity and sustaining soil health. SATSA Mukhapatra-Annu. Tech. Issue 2016, 20, 15-25.

19. Alam, M.K.; Bell, R.W.; Hasanuzzaman, M.; Salahin, N.; Rashid, M.H.; Akter, N.; Akhter, S.; Islam, M.S.; Islam, S.; Naznin, S.; et al. Rice (Oryza sativa L.) Establishment Techniques and Their Implications for Soil Properties, Global Warming Potential Mitigation and Crop Yields. Agronomy 2020, 10, 888.

20. Mohanta, S.; Banerjee, M.; Malik, G.C.; Shankar, T.; Maitra, S.; Ismail, I.A.; Dessoky, E.S.; Attia, A.O.; Hossain, A. Productivity and Profitability of Kharif Rice Are Influenced by Crop Establishment Methods and Nitrogen Management in the Lateritic Belt of the Subtropical Region. Agronomy 2021, 11, 1280. [CrossRef]

21. Bagayoko, M. 2012. Effects of plant density, organic matter and nitrogen rates on rice yields in the System of Rice Intensification (SRI) in the "OFFICE DU NIGER" in Mali. ARPN J. Agric. Biolo. Sci. 2012, 7, 620-632.

22. Man, Y.; Wang, B.; Wang, J.; Slaný, M.; Yan, H.; Li, P.; El-Naggar, A.; Shaheen, S.M.; Rinklebe, J.; Feng, X. Use of biochar to reduce mercury accumulation in Oryza sativa L: A trial for sustainable management of historically polluted farmlands. Environ. Int. 2021, $153,106527$.

23. Sahrawat, K.L. Soil fertility in flooded and non-flooded irrigated rice system. Arch. Agron. Soil Sci. 2012, 58, 423-436. [CrossRef]

24. Marschner, H. Mineral Nutrition of Higher Plants; Academic Press: London, UK, 1995.

25. Wang, Q.; Shaheen, S.M.; Jiang, Y.; Li, R.; Slaný, M.; Abdelrahman, H.; Kwong, E.; Bolanh, N.; Rinklebebg, J.; Zhang, Z. Fe/Mnand $\mathrm{P}$-modified drinking water treatment residuals reduced $\mathrm{Cu}$ and $\mathrm{Pb}$ phytoavailability and uptake in a mining soil. J. Hazard. Mater. 2021, 403, 123628.

26. Maitra, S.; Zaman, A.; Mandal, T.K.; Palai, J.B. Green manures in agriculture: A review. J. Pharm. Phytochem. 2018, 7, $1319-1327$.

27. Das, T.K.; Bhattacharyya, R.; Sharma, A.R.; Das, S.; Saad, A.A.; Pathak, H. Impacts of conservation agriculture on total soil organic carbon retention potential under an irrigated agro-ecosystem of the western Indo-Gangetic Plains. Eur. J. Agron. 2013, 51, 34-42. [CrossRef]

28. Midya, A.; Saren, B.K. Effect of brown manuring in Integrated Crop Management (ICM) for sustainable rice production. In Proceedings of the National Symposium on Recent Trends in Agriculture and Allied Sciences for Better Tomorrow (NSRTAS), Visva-Bharati, West Bengal, India, 4 December 2016.

29. Maitra, S.; Zaman, A. Brown manuring, an effective technique for yield sustainability and weed management of cereal crops: A review. Int. J. Bioresour. Sci. 2017, 4, 1-6. [CrossRef]

30. Subbiah, B.V.; Asija, G.L. A rapid procedure for the determination of available nitrogen in soils. Curr. Sci. 1956, 25, 259-260.

31. Jackson, M.L. Soil Chemical Analysis; Prentice Hall of India Pvt. Ltd.: New Delhi, India, 1973; p. 498.

32. Hanway, J.J.; Heidel, H. Soil analyses methods as used in Iowa State College Soil Testing Laboratory. Iowa Agric. 1952, 57, 1-31.

33. Walkley, A.J.; Black, I.A. Estimation of soil organic carbon by the chromic acid titration method. Soil Sci. 1934, 37, 29-38. [CrossRef]

34. Page, A.L.; Miller, R.H.; Keeney, D.R. Methods of Soil Analysis Part 2; Series ASA-SSSA Publishers; AGRONOMY; American Society of Agronomy, Inc. Soil Science Society of America, Inc. Publisher: Madison, WI, USA, 1982.

35. Lindsay, W.L.; Norvell, W.A. Development of a Dtpa soil test for zinc, iron, manganese, and copper. Soil Sci. Soc. Amer. J. 1978, 42, 421-428. [CrossRef]

36. Chesnin, L.; Yien, C.H. Turbid metric determination of available sulphates. Soil Sci. Soc. Am. J. 1950, 15, 149-151. [CrossRef]

37. Bouyoucos, G.J. Hydrometer method improved for making particle size analysis of soils. J. Agron. 1951, 54, 464.

38. Statistix 10 for Windows. Analytical Software. Tallahassee, FL, USA. 1998. Available online: https://www.statistix.com/free-trial/ (accessed on 1 July 2021). 
39. Bouman, B.A.M.; Peng, S.; Castaneda, A.R.; Visperas, R.M. Yield and water use of irrigated tropical aerobic rice systems. Agric. Water Manag. 2005, 74, 87-105. [CrossRef]

40. Peng, S.; Bouman, B.; Visperas, R.M.; Casteneda, A.; Nie, L.; Park, H.K. Comparison between aerobic and flooded rice in the tropics: Agronomic performance in an eight seasons experiment. Field Crops Res. 2006, 96, 252-259. [CrossRef]

41. Chapagain, T.; Riseman, A.; Yamaji, E. Assessment of System of Rice Intensification (SRI) and conventional practices under organic and inorganic management in Japan. Rice Sci. 2011, 18, 311-320. [CrossRef]

42. Belder, P.; Bouman, B.A.M.; Spiertz, J.H.J.; Peng, S.; Castaneda, A.R.; Visperas, R.M. Crop performance, nitrogen and water use in flooded and aerobic rice. Plant Soil 2005, 273, 167-182. [CrossRef]

43. Chapagain, T.; Yamaji, E. The effect of irrigation method, age of seedlings and spacing on crop performance, productivity and water-wise rice production in Japan. Paddy Water Environ. 2010, 8, 81-90. [CrossRef]

44. Kato, Y.; Okami, M. Root growth dynamics and stomatal behaviour of rice (Oryza sativa L.) grown under aerobic and flooded conditions. Field Crops Res. 2010, 117, 9-17. [CrossRef]

45. Kato, Y.; Okami, M.; Tajima, R.; Fujita, D.; Kobayashi, N. Root response to aerobic conditions in rice, estimated by Comair root length scanner and scanner-based image analysis. Field Crops Res. 2010, 118, 194-198. [CrossRef]

46. Morita, S.; Yamazaki, K. Root System. In Science of the Rice Plant; Matsuo, T., Hoshikawa, K., Eds.; Morphology Food and Agriculture Policy Research Centre: Tokyo, Japan, 1993; Volume 1, pp. 161-186.

47. Iida, S.; Shinmura, Y.; Uemori, A.; Kuzuna, K. Influence of irrigation management at the middle growing stage on rice plant growth and yield. Jpn. J. Crop Sci. 1990, 59, 413-418. [CrossRef]

48. Mahender Kumar, R.; Subba Rao, L.V.; Babu, V.R.; Gopalkrishnan, S.; Surekha, K.; Padmavathi, C.; Somasekhar, N.; Raghuveer Rao, P.; Sreenivas Prasad, M.; Latha, P.C.; et al. System of Rice Intensification: Its present status, future prospects and role in seed production in India. SATSA Mukhapatra- Annu. Tech. Issue 2013, 17, $22-43$.

49. Kannan, T.; Ponmurugan, P. Response of paddy (Oryza sativa L.) varieties to Azospirillum brasilense inoculation. J. Phytol. 2010, 2, 8-13.

50. Veeramani, P. Enhancement of mat nursery management and planting pattern (using rolling markers) in System of Rice Intensification (SRI) technique. Res. J. Agric. Sci. 2011, 2, 371-375.

51. Ranjitha, P.S.; Mahender Kumar, R.; Jayasree, G. Evaluation of rice (Oryza sativa L.) varieties and hybrids in relation to different nutrient management practices for yield, nutrient uptake and economics in SRI. Ann. Biol. Res. 2013, 4, 25-28.

52. Amanullah, K.; Almas, L.K. Partial Factor Productivity, Agronomic Efficiency, and Economic Analyzes of maize in wheat-maize cropping system in Pakistan. In Proceedings of the Selected Paper Prepared for Presentation at the Southern Agricultural Economics Association Annual Meetings, Atlanta, GA, USA, 31 January-3 February 2009. Available online: https://core.ac.uk/ download/pdf/6995666.pdf (accessed on 15 August 2021). 